\title{
インターネットを用いた薬剤師間情報交換・研修システムの構築と運用
} 大谷壽一, ${ }^{a}$ 松田真実, ${ }^{a}$ 掛樋麻里, ${ }^{a}$ 森千江子, $b$ 正岡民次, ${ }^{b}$ 澤田康文 ${ }^{*}, a$

\section{Development and Application of an Internet-Based Educational System to Share Pharmaceutical Case Reports between Pharmacists}

\author{
Hisakazu OHtAni, ${ }^{a}$ Mami Matsuda, ${ }^{a}$ Mari KAKeHI,${ }^{a}$ Chieko Mori, ${ }^{b}$ \\ Tamiji MASAOKA, ${ }^{b}$ and Yasufumi SAWADA ${ }^{*, a}$ \\ Department of Medico-Pharmaceutical Sciences, Graduate School of Pharmaceutical Sciences, \\ Kyushu University, a 3-1-1, Maidashi, Higashi-ku, Fukuoka 812-8582, \\ Japan and Fukuoka City Pharmacist Association, $b$ 1-1-1, \\ Imaizumi, Chuo-ku, Fukuoka 812-0021, Japan
}

(Received August 22, 2001; Accepted November 9, 2001)

\begin{abstract}
For pharmacists to enhance skill of pharmaceutical cares, it is necessary to learn many instructive clinical cases, which include drug-related incidences and checks of medication errors by pharmacists. However, these cases tend to be kept in each facility and there is no access to the cases for outside pharmacists. Therefore, we aimed to develop an internet-based educational system to gather such cases, append educational commentaries by university staffs, and share them between pharmacists. An exclusive site was set up on the world wide web (WWW) homepage of the Section of Biopharmaceutics, Graduate School of Pharmaceutical Sciences, Kyushu University (http://seizai.phar.kyushuu.ac.jp) on November 2000. Browsing was limited to registered pharmacists. Any pharmacist can be freely registered. Cases were collected via WWW-forms in the site. After educational commentaries and elucidation were appended, the cases were distributed to the registered pharmacists by e-mails and WWW pages. Many applications for membership have been sent from around Japan to have more than 50 members per month, and many cases have been contributed. These cases were distributed weekly by e-mail magazines. The developed system enabled us to share many educational cases of drug-related problems all over the country. This system could contribute to pharmacists to enhance their skills of pharmaceutical cares.
\end{abstract}

Key words — internet; medication errors; pharmacists; pharmaceutical education; world wide web; incidence reports

背景及び目的

近年，医療現場においては多くの医療ミスが発生 しているが，その多くは，医薬品の不適切な使用， いわゆる投薬ミスによるものであると考えられてい る. 投薬ミスによる死亡件数も年々増加していると 考えられ，事実，米国においては，1983 年から 1993 年の 10 年間で投薬ミス (medication errors) による死亡件数は 2.57 倍に増大したと報告されて いる. ${ }^{1)}$ 投薬ミスは患者に有害作用をもたらす可能 性があるが，海外での調査によると，有害作用が生 じた場合平均 4.6 日の入院期間の延長とともに，一

a) 九州大学大学院薬学研究院臨床薬学講座, b) 福岡市薬 剂師会

e-mail: sawada@phar.kyushu-u.ac.jp
症例あたり 4685 米ドルの余分な医療費がかかると

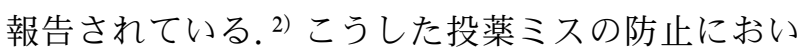
て，薬剤師が果たす役割は大きく，例えば，集中治 療室の治療に薬剤師が参画した場合，処方ミスが約 1/3にまで激減したとの報告がある.3)このよう に, 薬剤師の果たすリスクマネージャーとしての役 割に社会的注目が集まっている. ${ }^{4,5)}$ しかしながら， 現在の薬剤師養成教育においては, リスクマネージ ヤーとしての役割とこれを遂行するための知識・技 能・態度の修得は，卒業後の自己研鑽や研修教育に 委ねられているのが現状である.

薬剤師がこうした卒業後の研修や自己研鑽によつ て，リスクマネージャーとして十分な役割を果たす ことが出来るようになるためには，より多くの「事 例」に触れ，その防止法，解決法を修得することが 
不可欠である。ここで事例は，「ヒヤリハット事 例」，すなわち医療事故に至らなかった調剤ミス・ 調剤過誤などの事例と，「処方チェック」事例，す なわち薬剤師が実際にリスクマネージャーとして処 方ミスや投薬ミスを阻止した事例の二種に大別でき る。しかしこのような，資質向上のための「教科書」 ともいえる数多くの事例は, 医療事故に至って報道 された一部の事例を除いては，各医療機関において 死蔵されており，公にされることは少ない。このう ち後者の処方チェック事例の一部については近年, 「プレアボイド事例」として調査，報告が行われる ようになった。近年では，日本薬剤師会が調査主体 となり，全国の調査協力薬局を対象に「疑義紹介等 状況調査」が行われ，この結果の解析をもとに，医 薬品の適正使用における薬剂師と医薬分業が果たす

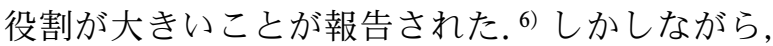

これらの報告は薬剤師と医薬分業の有用性を示す統 計的側面に主眼がおかれており，各事例について詳 細に検討を加え，薬剤師の知識・技能・態度の修得 と研鑽に役立てることを目的としたものではない．

一方，ヒヤリハット事例については，これを包み隠 さず報告し，組織的にその原因を探求し，事故防止 策をたてることが重要であるとされているが，事例 により得られる教訓の活用は各施設毎に任せられて いるのが実状であり,7)それらを薬剤師間で共有 し，薬剤師の資質を向上させるための試みはほとん ど行われていない。

そこで本研究においては，インターネットを活用 し，こうした事例を組織的に収集するとともに，そ れらの事例にエビデンスに基づく詳細な検討・解説 を加え，薬剤師の質的向上に役立つ「活きたテキス 卜」に再構築し，これを再度配信するためのシステ ムを構築・運用することを試みた。また，実際の薬 剤業務において具体的な問題点に遭遇した場合の相 談空口を提供することも併せて試みた。そしてこれ らのシステムの運用により，薬剤師の資質向上を介 して，医療ミスの低減に貢献することを目的とした。

\section{方}

\section{1. システムの構築システムにおける情報交} 換は，すべてインターネットを用いて行うものとし た。構築したシステムの概略を Fig. 1 に示す。ま ず，九州大学大学院薬学研究院臨床薬学講座製剤設
計学分野 (本学製剂設計学分野) のホームページ (http://seizai.phar.kyushu-u.ac.jp) に，本システム 用の WWW (world wide web) サイトとして，「薬 剂師さん碩張ろう」サイト（http:// seizai.phar. kyushu-u.ac.jp / members / pharmacist / pharmacist. html）を開設した。サーバは，Macintosh G3（iMac） DV400（メモリ 64 MB/ハードディスク 10 GB） (Apple Computer, Inc., Cupertino, CA) を用い，才 ペレーティングシステム（OS）は Mac OS J1-9.0.4 （Apple Computer, Inc., Cupertino, CA）を用いた。 WWW ページの作成には，Dreamweaver 3（日本語 版) Ver 3.0 (Macromedia, Inc., San Francisco, CA) を用いた。 Web サーバソフトには，Mac OS 附属の Web 共有 J1-1.5 を用い，これによりパスワードを 用いたアクセス制限を行った。WWW サイトへの アクセスは事前に登録を受けた薬剂師に限り，登録 並びに ID コード及びパスワードの発給は電子メー ルにより行った。登録にあたっては，登録薬劑師 名，連絡先電話番号，電子メールアドレス，勤務先 名，勤務先住所及び勤務先電話番号の 6 項目の情報 を要求した.

事例の収集はいずれも WWW 上の投稿フォーム を用いて行うシステムとした。 ヒヤリ・ハット事例 及び処方チェック事例の投稿フォームを Fig. 2 に 示す。いずれの事例においても，患者を特定できる 情報は入力項目としなかった。 フォームに入力され た事例情報は，CGI（common gate interface）を用 いて，入力者の ID コードとともにサーバ内のデー タベースに格納した。 CGI スクリプトは，スクリ プティング機能追加として Tanaka's OSAX を組み 込んだ Apple Script (Apple Computer, Inc., Cupertino，CA）により記述し，データベースソフトとし てはファイルメーカーPro Ver 3.0 (Filemaker Inc., Santa Clara, CA）を用いた.

収集した事例については，投稿者と電子メールを 用いて情報交換を行い，不足情報を補完するととも に，教育的見地から事例に科学的根拠及び解説を加 えた。これらの著作権は本学製剤設計学分野に属す る旨は，投稿フォームの WWW ページ上に明記し た。そして，解説等を付した事例を，登録薬郕師に 対して，電子メールによりメールマガジンとして送 信することとした。メールサーバーとして大学医療 情報ネットワーク（UMIN; university hospital med- 


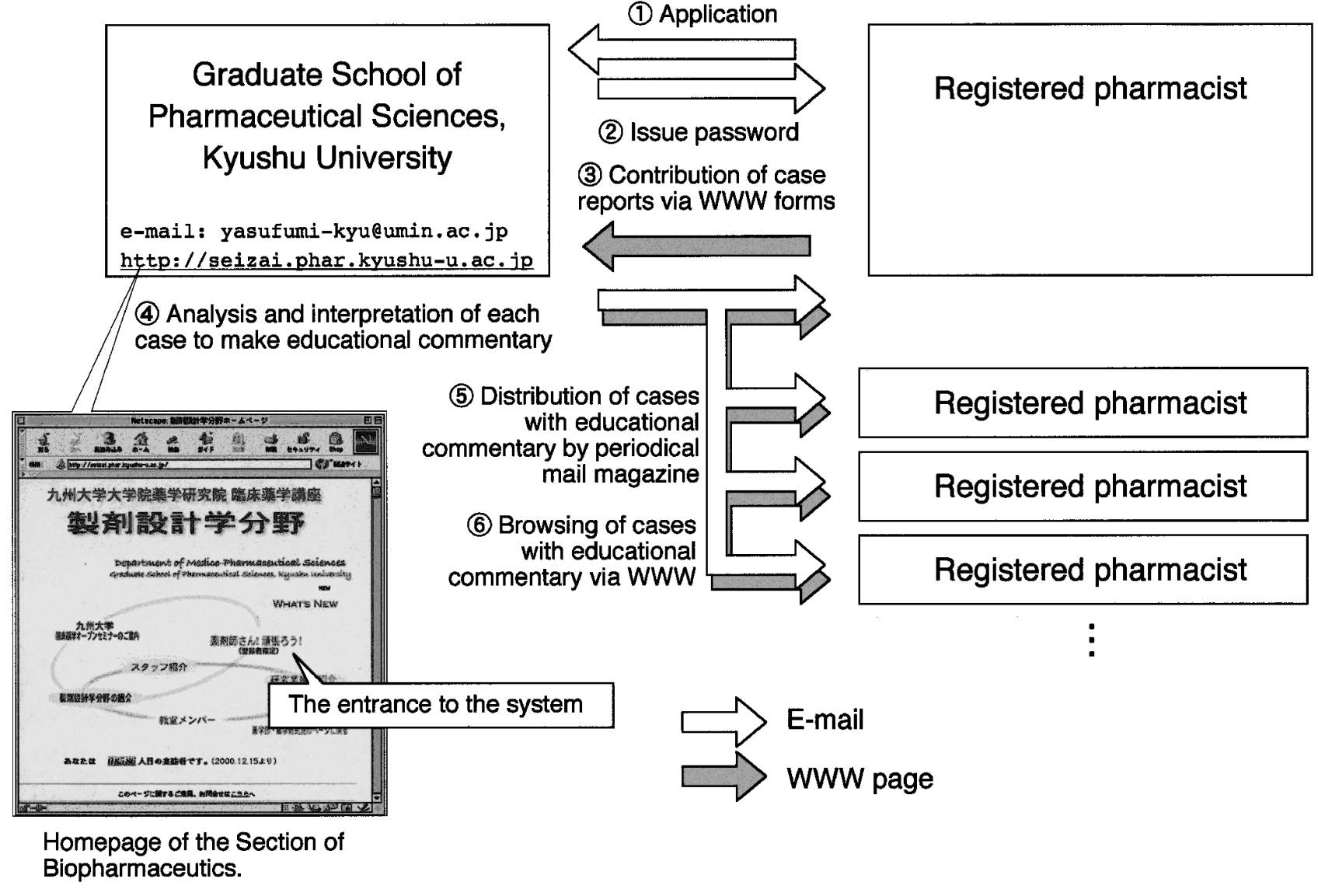

Fig. 1. A Schematic Diagram of the Developed System

ical information network）のメールサーバを用い, メールソフトとしては Outlook Express Ver 5.02 （Microsoft Corp., Redmond, WA）を用いた。また 同時に，送信した事例は WWW ページとして登録 薬剤師に対して公開した。

2. システムの運用 モニター薬剤師の公募及 び登録方法の周知は，平成 12 年 10 月より，専門誌 及び学会・各種講演会等において行った。ただし， 本学製剂設計学分野のホームページを介して登録申 込があった場合も，登録方法を通知した。事例の配 信は，ヒヤリ・ハット事例，処方チェック事例をそ れぞれ隔週で，登録薬剤師に対して電子メールによ り配信すると共に, 配信後 2 週間以内に WWW サ イトにおいて登録薬剤師に対して公開した。

また，本システムにより収集した事例を解析した 結果, 医薬品適正使用のために重要と考えられる内 容については，必要に応じて本学製剤設計学分野よ り関係機関に情報提供を行うこととした。
結果

1. システムの構築 平成 12 年 11 月に, 相互 作用コンサルティングコーナー以外のシステムの構 築が完了し，以後安定かつ継続的に運用することが できた。また，平成 13 年 2 月より，相互作用コン サルティングコーナーの構築が完了し，同様に安定 かつ継続的に運用することができた。開発した WWW サイトのサイトマップを Fig. 3 に示す.

2. システムの運用登録薬剤師の募集を行つ たところ，月間平均約 50 件の登録があった（Fig. 4)。また，登録薬剤師の勤務先は，人口比を考慮す ると本学が位置する福岡県並びにその近隣がやや多 かった点を除いては，全国各地から登録を受けるこ とができた（Table 1)。また，登録薬剤師の勤務施 設は，開局薬局が約半数を占めたものの，その他の 職種，すなわち病院，診療所，薬剤師会，大学など において勤務する薬剤師などからも，幅広く登録を 受けることができた（Table 2). 
(A)

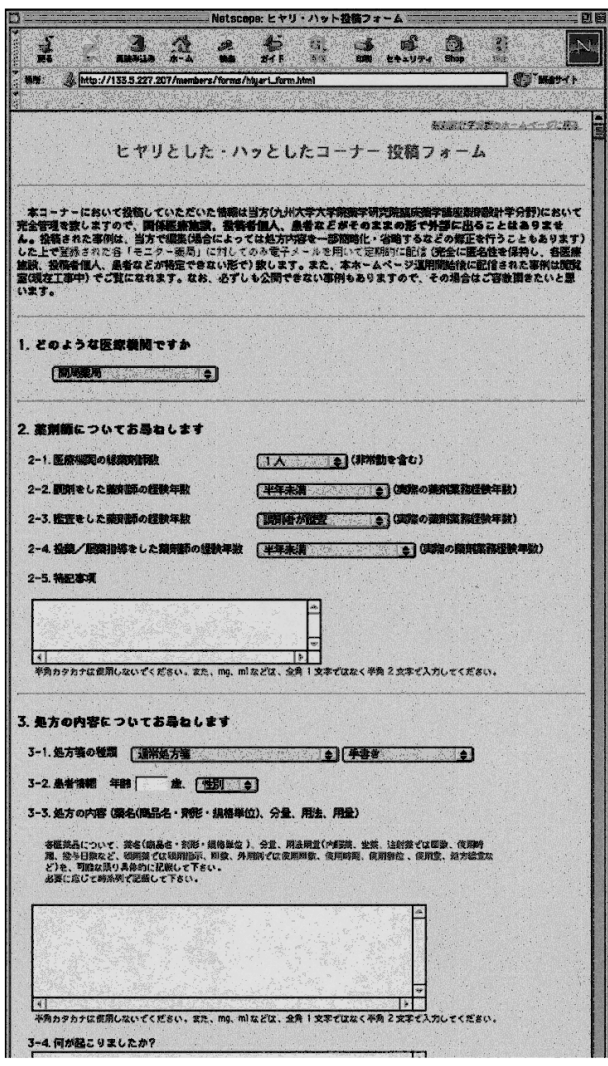

(B)

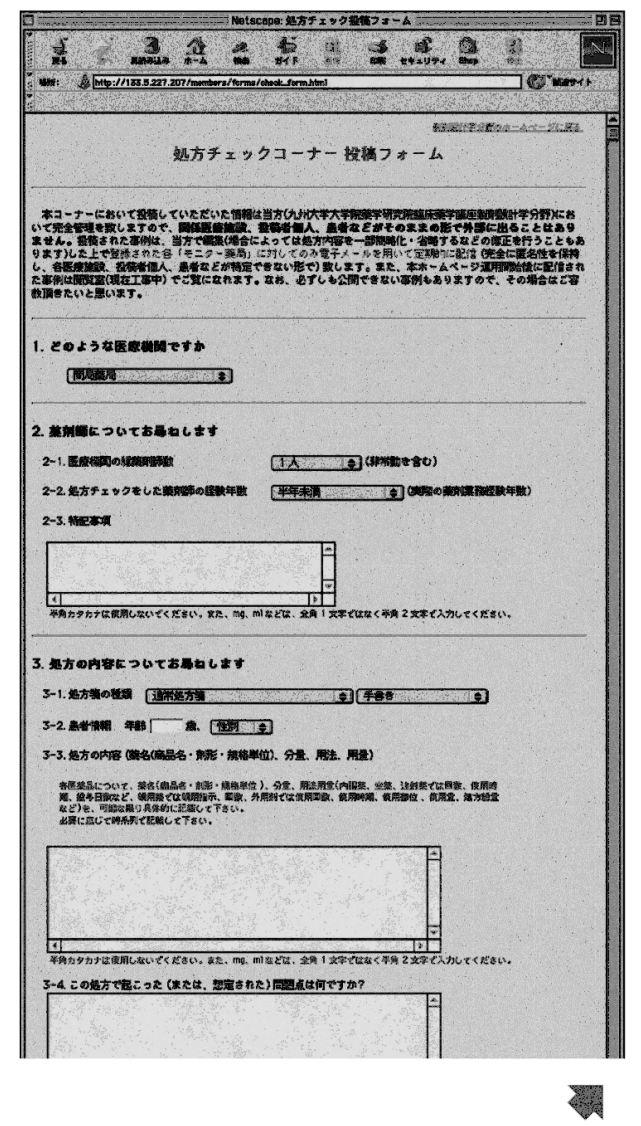

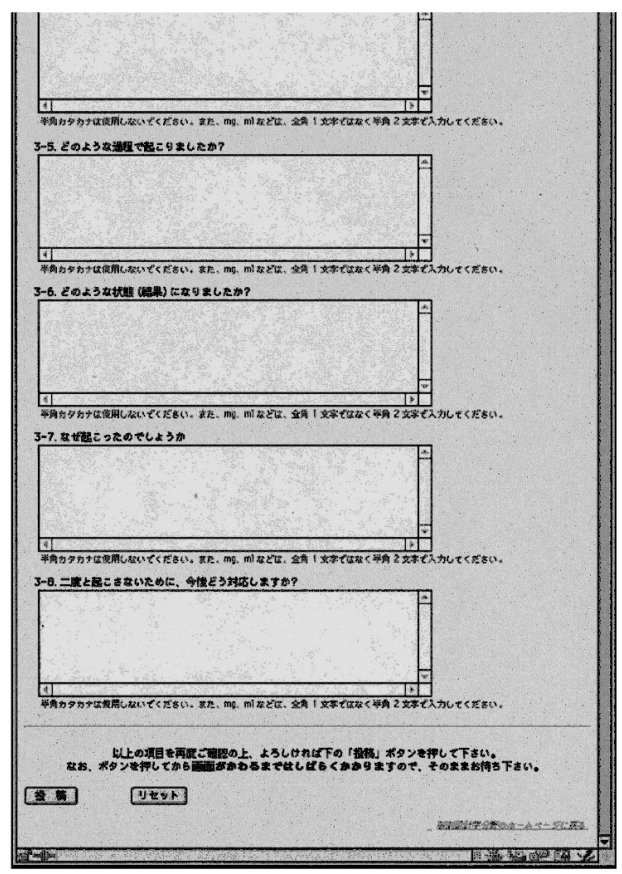

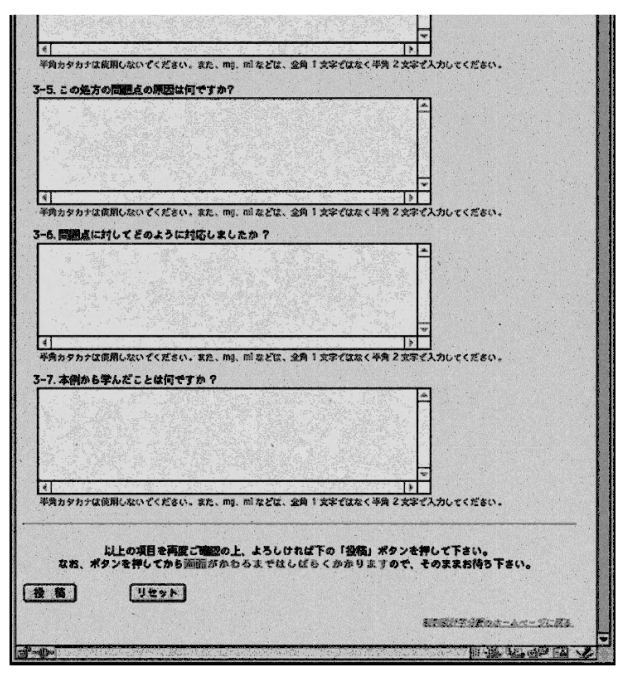

Fig. 2. WWW Forms for Contribution

(A) A form for incident reports, (B) A form for reports of the check of medication errors by pharmacists. 
また，運用開始後平成 13 年 8 月 16 日までの 9 力 月間で，ヒヤリ・ハット事例，処方チェック事例, 相互作用コンサルティングをそれぞれ $71,80,10$ 件 収集することができた。そして，これらの事例を解 析し解説を加え，ヒヤリ・ハット事例又は処方チエ ック事例を平成 12 年 12 月 20 日より週 1 件の割合 で，メールマガジンとして継続的に事例を登録薬剤 師に配信することができた。平成 13 年 8 月 10 日ま でに配信した事例の項目を Table 3 に示す。さら に，相互作用コンサルティングコーナーに寄せられ た相談内容のうち 3 件，すなわち「グレープフルー ツジュースとカルシウム拮抗薬の併用における相互 作用の持続期間」「ポリフル錠と $\mathrm{H}_{2}$ 受容体拮抗薬

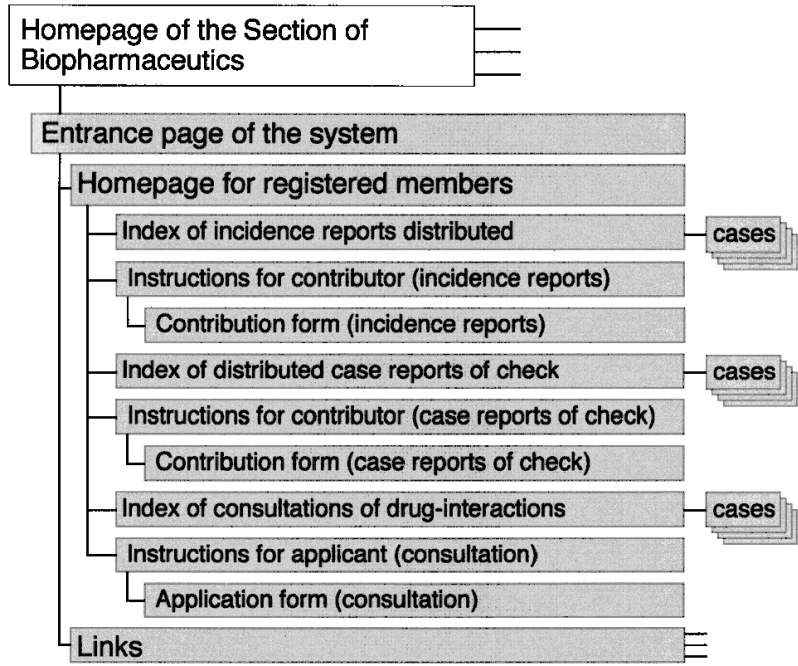

Fig. 3. A Site Map of the WWW Site of the Developed System

Access to the shadowed pages is limited to registered members.
の相互作用の可能性」「セフゾンとマグネシウム含 有製剂との併用可否」に対して，相談内容と回答を WWW ページ上に公開することができた.

一方，投稿された事例を整理・解析する過程にお いて，カロナール細粒（20\%アセトアミノフェン製 剂，昭和薬品化工株式会社，東京）について製剂量 と成分量の取り違えに基づく事例が多いことが判明 した。このため，平成 13 年 6 月 28 日に昭和薬品化 工株式会社に対し，文書による添付文書改訂の提案 を申し入れ，すみやかに担当者と協議を行った。そ して，添付文書改訂に先立ち，昭和薬品化工株式会

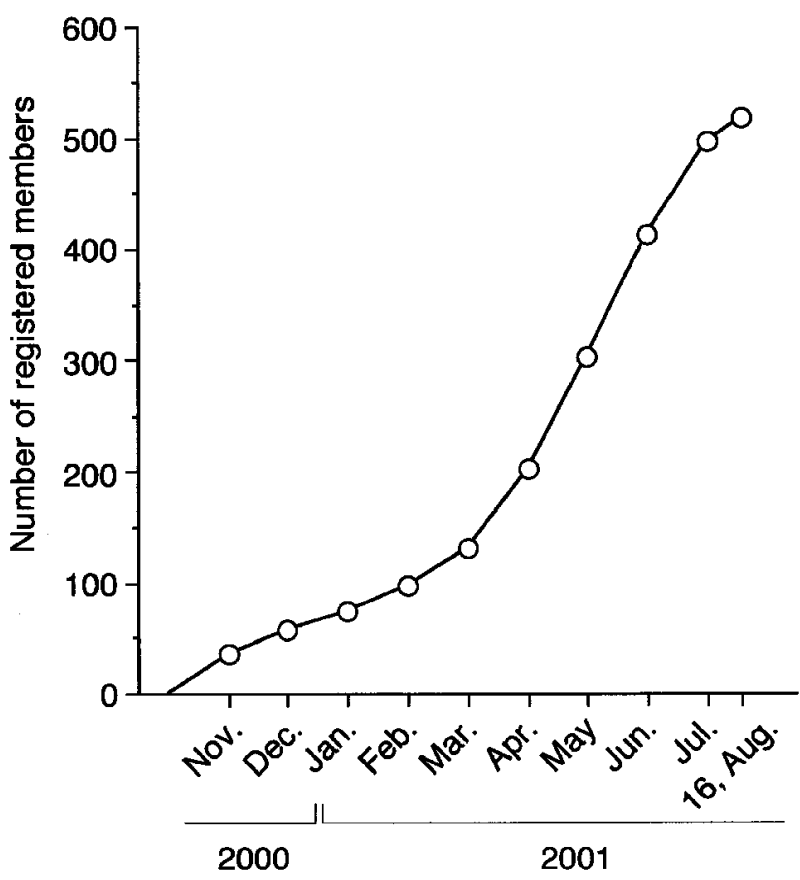

Fig. 4. Change in the Number of Registered Pharmacists

Table 1. Prefectural Distribution of the Registered Members of the System

\begin{tabular}{lrlrlrlr}
\hline \hline Hokkaido & 14 & Tokyo & 56 & Shiga & 4 & Tokushima & 2 \\
Aomori & 7 & Kanagawa & 33 & Kyoto & 12 & Ehime & 8 \\
Iwate & 1 & Yamanashi & 3 & Osaka & 7 & Kochi & 0 \\
Miyagi & 7 & Niigata & 7 & Hyogo & 20 & Fukuoka & 58 \\
Akita & 2 & Nagano & 7 & Nara & 6 & Saga & 6 \\
Yamagata & 0 & Toyama & 3 & Wakayama & 2 & Nagasaki & 20 \\
Fukushima & 6 & Ishikawa & 7 & Tottori & 0 & Kumamoto & 20 \\
Ibaraki & 11 & Fukui & 3 & Shimane & 8 & Oita & 12 \\
Tochigi & 1 & Shizuoka & 6 & Okayama & 2 & Miyazaki & 4 \\
Gunma & 8 & Aichi & 24 & Hiroshima & 12 & Kagoshima & 9 \\
Saitama & 16 & Mie & 4 & Yamaguchi & 14 & Okinawa & 1 \\
Chiba & 19 & Gifu & 8 & Kagawa & 14 & & \\
\hline
\end{tabular}


Table 2. Affiliations of the Registered Members of the System

\begin{tabular}{lcr}
\hline \multicolumn{1}{c}{ Affiliations } & Number & \multicolumn{1}{c}{$(\%)$} \\
\hline Hospital pharmacy & 147 & 28.3 \\
Infirmary & 15 & 2.9 \\
Pharmacy & 306 & 59.0 \\
Other medical/welfare facilities & 8 & 1.5 \\
University & 13 & 2.5 \\
Others*(incl. unknown) & 30 & 5.7 \\
\hline Total & 519 & 100.0 \\
\hline * Pharmaceutical company, government office, pharmacist's associa- \\
tion etc.
\end{tabular}

社より, 平成 13 年 7 月 11 日に社団法人日本薬剂師 会「日薬ニュース号外 34 号」として「アセトアミ ノフェン製剤「カロナール細粒」の【用法・用量】 䛊認による処方ミス防止と適正使用のお願い」を発 行し, 当該取り違えに注意するよう, 広く情報提供 を行うことができた，その後，同年 7 月中に「カロ ナール細粒」の添付文書が改訂された.

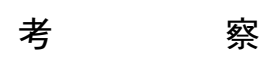

本システムは，薬剤師の資質向上に役立つと考え られる事例を，薬剤師間で共有することを目的とし た．登録者一名が経験した事例を投稿することによ り，本システムに登録しているすべての薬剤師が, その事例に基づいて学ぶことができる.こうした事 例の解析や症例検討会は, 従来施設内や地域の勉強 会で行われてきたが，本システムはこれを全国レベ ルで可能にしたものである.

インターネットを用いた薬剤師間の情報交換の方 法としては，WWW 上に解説したメーリングリス トや掲示板の活用，医薬関係のメールマガジンなど が試みられている。しかし，これらのいずれか単独 では，実際の事例を系統的に収集し，紹介すること は困難である。また，事例を系統的に収集するため のシステムとしては，プレアボイド報告などがあ り，一定の成果をあげている。7)しかし，その多く は事例を系統的に解析し, 薬剂師の資質向上に役立 てることを目的とはしておらず，情報の交換も一方 的であるといえる，さらに，ヒヤリ・ハット事例に 至っては, 全国レベルでこれを系統的に解析し, 薬 剂師の資質向上に役立てる試みは全くなされていな い。これらの観点から, 本システムは, 薬剤師の資 質向上を目的とした，最初の全国レベルでの情報交
換システムであるといえる.

本システムの継続的運営にあたっては, 事例の内 容を詳細に検討・解析し，エビデンスに基づいた解 説を加えるという作業を常に行う必要がある。これ を监路なく継続するためには, 大学薬学部の臨床薬 学系講座などといつた, 医療情報と薬学情報の構 築, 整理, 提供に精通した施設と人員が不可欠と考 えられる。したがって, 今回のようなシステムの構 築と運営は, 大学の社会貢献の一環としても, 極め て重要な位置を占めるものと考えられる．現在，こ うした事例の解析作業は著者らが中心に行っている が, 今後の登録薬剂師数の増大に伴い, 事例の投稿 件数も増加することが見込まれる. したがって今後 はこうした業務をどのように処理していくかが $1 つ$ の課題となるであろう.

本システムは，登録した薬剤師に対してのみ情報 交換・公開を許可している。このようなアクセス制 限は，医薬関係職に従事する者以外の不特定多数の 人々に不用意な不安を与えないためには必定である と考えられる。ささらに，登録者を同定することによ り，事例の定期的配信が可能になった。これによ り，積極的に本システムのサイトにアクセスするこ となしに，資質向上に役立つ情報が入手できるとい う点ですぐれていると考えられる. しかし一方で, 収集・解析した事例の恩恵に浴することができる薬 剤師が登録薬剂師に限られてしまい, 広く医療現場 に貢献できないという欠点がある。これを解決する ための 1 つの手段としては, 本システムの存在と趣 旨を周知徹底し, 登録薬剂師の数を大幅に増加させ るという方法がある。 また他の方法としては, 解析 した事例を出版物などの形で医療関係者に公開する という方法が考えられる．今後はこれらの方法によ り，本システムの成果をより多くの薬剤師に還元で きるよう努力する必要があろう。

現在までに本システムの成果が広く医療現場に還 元された例として, 医療用添付文書記載方法の改善 があげられる。すなわち，収集した事例をもとに， カロナール細粒に関し，社団法人日本薬剂師会「日 薬ニュース号外 34 号」において「アセトアミノフ エン製剤「カロナール細粒」の【用法・用量】誤認 による処方ミス防止と適正使用のお願い」として広 く情報提供を行うと共に,「カロナール細粒」添付 文書の改訂作業を開始する端緒を提供することがで 
Table 3. Clinical Case Reports E-Mailed to Registered Pharmacists (until 10, August 2001)

A. Incidence reports

\begin{tabular}{lc}
\hline \hline \multicolumn{1}{c}{ Titles } & $\begin{array}{c}\text { Date of } \\
\text { distribution }\end{array}$ \\
\hline Exchange of an antidiabetic drug between patients & 2000.12 .20 \\
A patient who ingested thrice dose of tablets after missed dose & 2001.1 .3 \\
Nitroglycerin patches were improperly used for myalgia. & 2001.1 .17 \\
"Dispensing error" + "disregard of query" + "impoliteness to patient", & 2001.1 .31 \\
Call the product name for strict preparation procedure! & 2001.2 .16 \\
A distribution error of instruction paper & 2001.3 .1 \\
Never change the prescription without doctor's approval! Never! & 2001.3 .16 \\
A laxative contraindicated in patients under dialysis. & 2001.3 .31 \\
Improper dosage schedule lead to sleep disorder & 2001.4 .12 \\
Preparation error caused by an association of generic name & 2001.4 .25 \\
Beta-blocker was administered to a patient with asthma even though a pharmacist advised. & 2001.5 .11 \\
A check made another check neglected. & 2001.5 .25 \\
A query of a patient: Does mecobalamin contains radioactive cobalt? & 2001.6 .7 \\
Omeprazole tablets were smashed according to the doctor's instruction. & 2001.6 .21 \\
A veteran part-timer also made a medication error & 2001.7 .5 \\
Prescription is not always standardized. & 2001.7 .26 \\
Dispensing error caused by various factors & 2001.8 .1 \\
\hline
\end{tabular}

B. Reports of the check of medication errors by pharmacists

\begin{tabular}{|c|c|}
\hline Titles & $\begin{array}{c}\text { Date of } \\
\text { distribution }\end{array}$ \\
\hline A prescribing error prevented by medication counseling & 2000.12 .26 \\
\hline Check of prescribing error from higher dosage regiment & 2001. 1.10 \\
\hline Cefdinir and iron salt & 2001. 1.23 \\
\hline Ravona $^{\circledR}$ is scarcely prescribed for such a patient. & 2001. 2. 8 \\
\hline Why the plastic surgeon prescribed Travelmin ${ }^{\circledR} ?$ & 2001. 2.23 \\
\hline Check of withdrawal phenomena of alprazolam & 2001.3. 8 \\
\hline Pharmacist detected an adverse reaction associated with biperiden. & 2001. 3.23 \\
\hline Drug consultation prevented a prescribing error of antidiabetic drug & 2001. 4. 5 \\
\hline Does the patient know how to use 5\% chlorhexidine gluconate? & 2001. 4.19 \\
\hline Carefully substitute $\mathrm{UFT}^{\oplus}$ for TS $-1^{\oplus} !$ & 2001. 5. 3 \\
\hline Adjust the dosage regiment to accustomed OTC. & 2001. 5.17 \\
\hline Check of withdrawal phenomena of fluvoxamine & 2001. 5.31 \\
\hline Increase in the dose of warfarin during phenobarbital treatment & 2001. 6.14 \\
\hline Duplication of same Chinese herbal medications with different brand & 2001. 6.28 \\
\hline Confusion of $100 \%$ and $20 \%$ acetaminophen powders & 2001. 7.12 \\
\hline Dan Rich $^{\circ}$ contains PPA, which is contraindicated in hypertension. & 2001. 7.19 \\
\hline Only women could check? & 2001. 8.9 \\
\hline
\end{tabular}

きた。今後も，本システムを運用し，事例の収集な ごを通じて，医療現場におけるさまざまな問題点を 見出し，医薬品の適正使用を目指した働きかけを行 つていく必要があるだろう。

以上，インターネットを活用した薬剤師相互の情 報交換・研修システムを構築することができた。さ らに，システムの運用により，薬剤師の資質向上に
有用な事例を系統的に多数収集するとともに，収集 した事例に解析，解説を加え，全国の薬剂師に定期 的に配信することができた。また，収集した事例を もとに，添付文書記載方法の問題点を改善するため の端緒を提供することができた。今回構築したシス テムは，薬剤師間の事例情報の交換と，卒後研修， 自己研鑽において，極めて有効なシステムになり得 
るであろうと考えられる.

補遺平成 14 年 1 月 10 日現在, 登録薬剤師数 は 865 名, メールマガジンによる配信事例数はヒヤ リ・ハット事例, 処方チェック事例各 28 例となつ た.

\section{REFERENCES}

1) Phillips D. P., Christenfeld N, Glynn L. M., Lancet, 351, 643-644 (1998).

2) Bates D. W., Spell N., Cullen D. J., Burdick E., Laird N., Petersen L. A., Small S. D.,
Sweitzer B. J., Leape L. L., JAMA, 277, 307311 (1997).

3) Leape L. L., Cullen D. J., Clapp M. D., Burdick E., Demonaco H. J., Erickson J. I., Bates D. W., JAMA, 282, 267-270 (1999).

4) Sawada Y., The Asahi Shinbun (Asahi Newspaper), May 10 (2000).

5) Sawada Y., FARUMASHIA, 37, 49 (2001).

6) Nakamura T., Kamei M., Suganuma T., J. Jpn. Pharm. Assoc., 51, 1860-1877 (1999) .

7) Japan Pharmaceutical Association, J. Jpn. Pharm. Assoc., 53, 7-54 (2001). 